\title{
Estrogen Levels in Childhood Determined by an Ultrasensitive Recombinant Cell Bioassay
}

Karen Oerter Klein, ${ }^{\ddagger}$ Jeffrey Baron, Michael J. Colli, Donald P. McDonnell, ${ }^{\star}$ and Gordon B. Cutler, Jr. Developmental Endocrinology Branch, National Institute of Child Health and Human Development, National Institutes of Health, Bethesda, Maryland 20892; *Department of Pharmacology, Duke University Medical Center, Durham, North Carolina 27710; and ${ }^{\ddagger}$ Children's Hospital of Orange County, Orange, California 92668

\begin{abstract}
We hypothesized that estradiol levels are higher in prepubertal girls than in prepubertal boys and that this greater secretion of estradiol might drive the more rapid epiphyseal development and earlier puberty in girls. Since previous estradiol assays have lacked adequate sensitivity to test the hypothesis of higher estradiol levels in girls, we developed a new ultrasensitive assay to measure estrogen levels. The assay uses a strain of Saccharomyces cerevisiae genetically engineered for extreme sensitivity to estrogen. Yeast were transformed with plasmids encoding the human estrogen receptor and an estrogen-responsive promoter fused to the structural gene for $\beta$-galactosidase. Ether extracts of $0.8 \mathrm{ml}$ of serum were incubated with yeast for $8 \mathrm{~h}$ and the $\beta$ galactosidase response was used to determine estrogen bioactivity relative to estradiol standards prepared in charcoalstripped plasma. The assay was highly specific for estradiol with $<3 \%$ cross-reactivity with estrone, estriol, or estradiol metabolites. The detection limit was $<0.02 \mathrm{pg} / \mathrm{ml}$ estradiol equivalents (100-fold lower than existing assays). Using this assay, we measured estrogen levels in 23 prepubertal boys $(9.4 \pm 2.0 \mathrm{yr})$ and 21 prepubertal girls (7.7 \pm 1.9 [SD] yr). The estrogen level in girls, $0.6 \pm 0.6 \mathrm{pg} / \mathrm{ml}$ estradiol equivalents, was significantly greater than the level in boys, $0.08 \pm 0.2 \mathrm{pg} / \mathrm{ml}$ estradiol equivalents $(P<0.05)$. We conclude that the ultrasensitive recombinant cell bioassay for estrogen is approximately $\mathbf{1 0 0}$-fold more sensitive than previous estradiol assays, that estrogen levels are much lower prepubertally, in both sexes, than reported previously, and that prepubertal girls have 8-fold higher estrogen levels than prepubertal boys. (J. Clin. Invest. 1994. 94:2475-2480.) Key words: prepubertal • yeast - Saccharomyces cerevisiae • estradiol • estrogen
\end{abstract}

\section{Introduction}

Estradiol exerts important biological effects at concentrations below the detection limit of available radioimmunoassays. For example, estradiol levels are usually undetectable at thelarche (1). Moreover, the onset of the pubertal growth spurt in girls

Karen Oerter Klein, Jeffrey Baron, and Gordon B. Cutler, Jr. are officers in the United States Public Health Service.

Address correspondence to Dr. Karen Oerter Klein, Building 10, Room 10N262, National Institutes of Health, Bethesda, MD 20892.

Received for publication 20 April 1994 and in revised form 2 September 1994.

The Journal of Clinical Investigation, Inc.

Volume 94, December 1994, 2475-2480 precedes thelarche, suggesting that skeletal growth can be driven by still lower levels of estradiol (2). Androgens are unlikely to be the cause of this growth spurt, since the onset of the growth spurt in boys is much later than in girls, despite their having equal or higher levels of androgen. Consistent with this view, the infusion of estradiol at the dose of $4 \mu \mathrm{g} / \mathrm{d}$ causes a tripling of ulnar growth rate in boys (3). The plasma estradiol level corresponding to this dose is $\sim 4 \mathrm{pg} / \mathrm{ml}$ based on extrapolation from the levels at higher dose infusions. Additionally, ethinyl estradiol doses as low as $25-100 \mathrm{ng} / \mathrm{kg}$ per day cause increased growth velocity in girls with Turner syndrome (4-6).

We hypothesized that circulating levels of estradiol in girls are higher than in boys and that this estradiol drives skeletal growth and maturation. This hypothesis would explain the observation that skeletal maturation proceeds more rapidly in prepubertal girls than boys (7). Furthermore, children with luteinizing hormone-releasing hormone-independent precocious puberty, who initially have high sex steroid levels but low gonadotropin levels, have an earlier pubertal rise in gonadotropin levels than normal children (8). By analogy, the hypothesis of higher prepubertal estradiol levels in girls might also explain the observation of an earlier onset of puberty in girls than in boys (2).

The possibility of higher estradiol levels in girls than in boys has not been resolved previously because of the lack of sensitivity of available assays for estradiol. Previous reports of estradiol levels in prepubertal children include the observation by Forest et al. (9) and others (10-12) of a neonatal surge of estradiol and descriptions by others of estradiol levels in older prepubertal children that were $\sim 8 \mathrm{pg} / \mathrm{ml}$ and were similar in both boys and girls (13-16). These levels were so close to the detection limit of the assay that they were of questionable reliability (13). Thus, to test the hypothesis of greater secretion of estradiol in prepubertal girls than in prepubertal boys, we developed a new ultrasensitive recombinant cell bioassay $(\mathrm{RCBA})^{1}$ to measure extremely low levels of estrogen. We used this assay to measure estrogen levels in 44 normal prepubertal girls and boys.

\section{Methods}

Plasmids. The plasmid, YEPKB1, contains the CUP1 metallothionein promoter fused to the human estrogen receptor cDNA. The reporter plasmid, YRPE2, contains two copies of the frog vitellogenin estrogen response element (ERE) upstream of the yeast iso-1-cytochrome $c$ promoter fused to the structural gene for $\beta$-galactosidase. The Saccharo-

1. Abbreviations used in this paper: $\mathrm{CV}$, variation; DES, diethylstilbestrol; ERE, estrogen response element; ONPG, ortho-nitrophenolgalactopyranoside; RCBA, recombinant cell bioassay. 
myces cerevisiae strain BJ3505 (MATa,ura3-52,tryp1 $\Delta 101$, lys2-208) was transformed with these two plasmids (17-19). Transformants were selected by tryptophan or uracil auxotrophy $(20,21)$.

Standards. Pooled plasma from adult men plus charcoal $(3 \mathrm{~g} / 100$ $\mathrm{ml}$ )(Norit A; Fisher Scientific Co., Fairlawn, NJ) was stirred for 30 min at room temperature and then overnight at $4^{\circ} \mathrm{C}$ and then was filtered successively through glass wool and a $0.2-\mu \mathrm{m}$ filter (Corning Glassworks, Corning, NY). A known amount of estradiol (Sigma Immunochemicals, St. Louis, MO) was dissolved in ethanol (Midwest Grain Products, Pekin, IL) and diluted serially in ethanol to yield concentrations from $5 \times 10^{-12}$ to $5 \times 10^{-7} \mathrm{M}$. $0.05 \mathrm{ml}$ of each solution of estradiol was added to $25 \mathrm{ml}$ of charcoal-stripped plasma to obtain a set of estradiol standards with concentrations from $10^{-13}$ to $10^{-7} \mathrm{M}$. Each standard pool was divided into aliquots of $1.6 \mathrm{ml}$ and frozen for future use.

Standards were prepared in charcoal-stripped plasma to avoid a negative blank that occurred when ether extracts of plasma were assayed against an estradiol standard curve that had not been exposed to plasma (data not shown).

Blood collection and serum separation. Blood was collected in glass vacutainer tubes that were kept upright at all times to avoid contamination with substances in the rubber stoppers that otherwise cross-reacted in the assay. Blood was spun, and the serum phase was removed and immediately frozen in polypropylene tubes.

Extraction. Ether $(0.8 \mathrm{ml})$ (ChromAR; Malinkrodt, Paris, KY) was added to $0.8 \mathrm{ml}$ serum sample or plasma standard, vortexed, and centrifuged to separate the phases. The aqueous phase was frozen by submerging the tubes in a dry ice/methanol bath. The ether phase was transferred to sterile glass $12 \times 75-\mathrm{mm}$ tubes (Kimble/Kontes, Vineland, NJ) and evaporated at $40^{\circ} \mathrm{C}$.

Yeast culture. Yeast were grown in selective media containing a filter-sterilized solution of glucose $(20 \mathrm{~g} /$ liter $)$ (Sigma Immunochemicals), yeast nitrogen base without amino acids $(6.7 \mathrm{~g} /$ liter ) (Difco Laboratories Inc., Detroit, MI), adenine sulfate ( $0.032 \mathrm{~g} /$ liter ) (GIBCO BRL, Gaithersburg, MD), and casamino acids (autoclaved in distilled water to destroy the tryptophan, $5 \mathrm{~g} /$ liter ) (Difco Laboratories Inc.). The transformed yeast strain was stored at $-80^{\circ} \mathrm{C}$ in $15 \%$ glycerol ( vol/vol) (Malinkrodt). 3-7 d before running the assay, an agar ( $20 \mathrm{~g} / \mathrm{liter})$ (Difco Laboratories Inc.) plate of the selective media was inoculated with yeast from the frozen stock. The plate was incubated at $30^{\circ} \mathrm{C}$ for $36 \mathrm{~h}$ and then stored at $4^{\circ} \mathrm{C}$. The evening before running the assay, a single colony of yeast from the agar plate was used to inoculate 1-2 $\mathrm{ml}$ of the selective media. The culture was incubated by shaking at $30^{\circ} \mathrm{C}$ overnight. In the morning, the yeast were diluted to an optical density $(600 \mathrm{~nm})$ of 0.2 in selective media and induced with $100 \mu \mathrm{M}$ copper sulfate (Sigma Immunochemicals). $0.1 \mathrm{ml}$ of this cell suspension was placed in each of the $12 \times 75-\mathrm{mm}$ glass test tubes containing the extracted estradiol. Tubes were covered with parafilm and incubated for $8 \mathrm{~h}$ at $30^{\circ} \mathrm{C}$ while shaking at $50 \mathrm{rpm}$. The conditions of the assay procedure were optimized by examining the effect of time of incubation of the cells and time of exposure of the cells to estrogen on the sensitivity of the assay. An 8-h incubation, with cells reaching the late log phase of growth by the end of incubation, was optimal; the concentration of yeast was maximized, and the volume of media was minimized to increase sensitivity (data not shown).

$\beta$-Galactosidase assay. $\beta$-Galactosidase activity was assayed by a modification of previous methods $(22,23)$. After incubation, the yeast culture samples were transferred to conical 0.6-ml RIA tubes (so that a multitip pipetter could be used throughout the remainder of the assay for efficiency and reproducibility)(Sarstedt, Inc., Newton, NC) and centrifuged at $4,000 \mathrm{~g}$ for $10 \mathrm{~min}$ at $4^{\circ} \mathrm{C}$ to pellet the cells. The supernatant was removed by suction, and the cells were resuspended in $150 \mu \mathrm{l}$ of $\mathrm{Z}$ buffer $\left(\mathrm{Na}_{2} \mathrm{HPO}_{4} \cdot 7 \mathrm{H}_{2} \mathrm{O} 16.1 \mathrm{~g} /\right.$ liter, $\mathrm{NaH}_{2} \mathrm{PO}_{4} \cdot \mathrm{H}_{2} \mathrm{O} 5.5 \mathrm{~g} /$ liter, $\mathrm{KCl} 0.75 \mathrm{~g} /$ liter, $\mathrm{MgSO}_{4} \cdot 7 \mathrm{H}_{2} \mathrm{O} 0.245 \mathrm{~g} /$ liter, $\beta$-mercaptoethanol 2.7 $\mathrm{ml} /$ liter)(Sigma Immunochemicals) (24). The cells were permeabilized by mixing with $30 \mu \mathrm{l}$ of chloroform (Malinkrodt). The chloroform was allowed to separate for $5 \mathrm{~min}$ before $100 \mu \mathrm{l}$ of the supernatant was removed and placed in a flat-bottom microtiter plate along with $60 \mu \mathrm{l}$ of $\mathrm{Z}$ buffer. Cell density was estimated by measuring light scattering using a microtiter plate reader (Multiscan Plus; Titretek). $40 \mu \mathrm{l}$ of the colorless substrate ortho-nitrophenolgalactopyranoside (ONPG) (Sigma Immunochemicals; $3.3 \mathrm{mg} / \mathrm{ml}$ in $\mathrm{Z}$ buffer) was added to each well, and the plate was incubated at $30^{\circ} \mathrm{C}$. The change in concentration of orthonitrophenol, the yellow product that results from $\beta$-galactosidase cleavage of ONPG, was determined by making serial measurements over $6 \mathrm{~h}$ using the microtiter plate reader at $416 \mathrm{~nm}$. $\beta$-Galactosidase activity was determined from the change in OD $(416 \mathrm{~nm})$ during the initial phase of linear increase divided by elapsed time and the initial cell scattering. The activity of high levels was determined from the rate of product accumulation during the first 2-4 min after ONPG was added. The activity of very low levels was determined from the absorbance at $4-6 \mathrm{~h}$ after ONPG was added.

$\beta$-Galactosidase activity was converted to estradiol equivalent units by linear interpolation from the standard curve constructed by adding known amounts of estradiol to charcoal-stripped plasma samples.

Subjects. We studied 44 normal prepubertal children. There were 21 girls (age $7.5 \pm 2.1$ [SD] yr, range $5.5-10.5 \mathrm{yr}$ ) and 23 boys $(9.5 \pm 2.1$ yr, range $4.5-13 \mathrm{yr}$ ). All participants had normal physical examinations, height and weight within 2 SD of the mean for age, no history of significant past medical illnesses, and no use of estrogen-containing creams or compounds. All children were prepubertal, defined as no axillary or pubic hair, no breast tissue in the girls, and testicular volume $\leq 3 \mathrm{ml}$ in the boys. The children were seen in the outpatient department for a single blood sample. The study protocol was approved by the National Institute of Child Health and Human Development Institutional Review Board, and informed assent was given by each child and informed consent by one parent.

\section{Results}

Standard curve. Known amounts of estradiol were added to charcoal-stripped plasma samples (Fig. 1). The background activity in the absence of estradiol was very low. The $\beta$-galactosidase activity increased 1,000 -fold in response to estradiol. The working range of the assay was also at least three orders of magnitude of estradiol concentration.

Sensitivity. The sensitivity of the assay, defined as the estradiol concentration that resulted in $\beta$-galactosidase activity 2 standard deviations above the mean of 10 samples of charcoalstripped plasma, was $<0.02 \mathrm{pg} / \mathrm{ml}$.

Precision. The intraassay variation (CV) was estimated by assaying the same plasma pool eight times in a single assay. At $2 \mathrm{pg} / \mathrm{ml}$ estradiol, the intraassay CV was $15 \%$. As one approached the detection limit of $0.02 \mathrm{pg} / \mathrm{ml}$, the $\mathrm{CV}$ increased to $\sim 50 \%$. The interassay variation was estimated by assaying duplicate samples from a plasma pool on six separate days. At $2 \mathrm{pg} / \mathrm{ml}$ estradiol, the interassay $\mathrm{CV}$ was $13 \%$. As one approached the detection limit, the interassay $\mathrm{CV}$ increased to $\sim 60 \%$.

Recovery. Recovery was determined by adding known amounts of radiolabeled estradiol to charcoal-stripped plasma. Recovery averaged $93 \pm 17 \%$.

Accuracy. Accuracy was determined by comparing the estrogen determinations from the new ultrasensitive RCBA with the determinations from an existing estradiol radioimmunoassay (Hazleton Biologics, Inc., Lenexa, KS ). 40 normal female serum samples were used for both determinations. The correlation coefficient was 0.90 (Fig. 2).

Specificity. The assay specificity was tested by adding known amounts of the following steroids to charcoal-stripped plasma samples: estriol, estrone, 17- $\alpha$ estradiol, estradiol 17glucuronide, estradiol 3-sulfate, estriol 3-glucuronide, estriol 


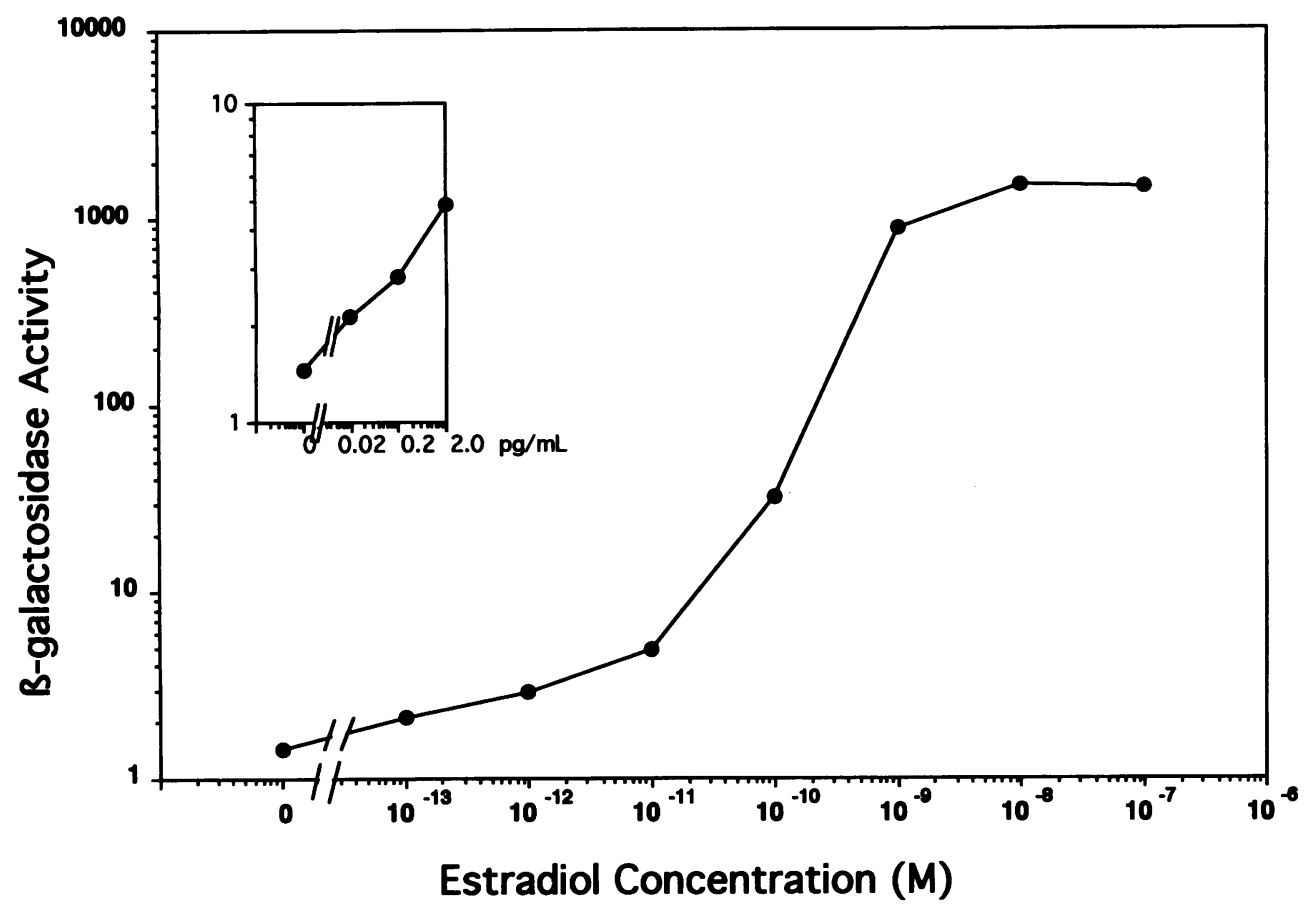

Figure 1. Dose response curve. $\beta$ Galactosidase activity ( $y$ axis) versus concentration of estradiol added to charcoal-stripped plasma ( $x$ axis). The inset shows the low end of the standard curve. The unit of $\beta$-galactosidase activity is 1,000 times the change in optical density $(416 \mathrm{~nm})$ per minute divided by the optical density of the cells. 3-sulfate, estrone glucuronide, estrone 3-sulfate, testosterone, dexamethasone, cortisol, aldosterone, progesterone, diethylstilbestrol (DES), ethinyl estradiol, and mestranol (Sigma Immunochemicals, except estrone and estrone glucuronide which were from Steraloids, Wilton, NH).

The assay was highly specific for estradiol with low crossreactivity for estrone $(0.3 \%)$, DES $(<3 \%)$, estriol $(0.03 \%)$, estrogen metabolites $(<2 \%)$ (Fig. 3$)$, testosterone, aldosterone, progesterone, and cortisol ( $<0.01 \%$, data not shown). The cross-reactivity for commonly used synthetic estrogens was $100 \%$ for ethinyl estradiol and $0.4 \%$ for mestranol. $17-\alpha$ estradiol had a cross-reactivity of $9 \%$ (data not shown).

Patient data. The mean estrogen level in prepubertal boys was $0.08 \pm 0.2 \mathrm{pg} / \mathrm{ml}$ estradiol equivalents (range $<0.02$ to 0.7

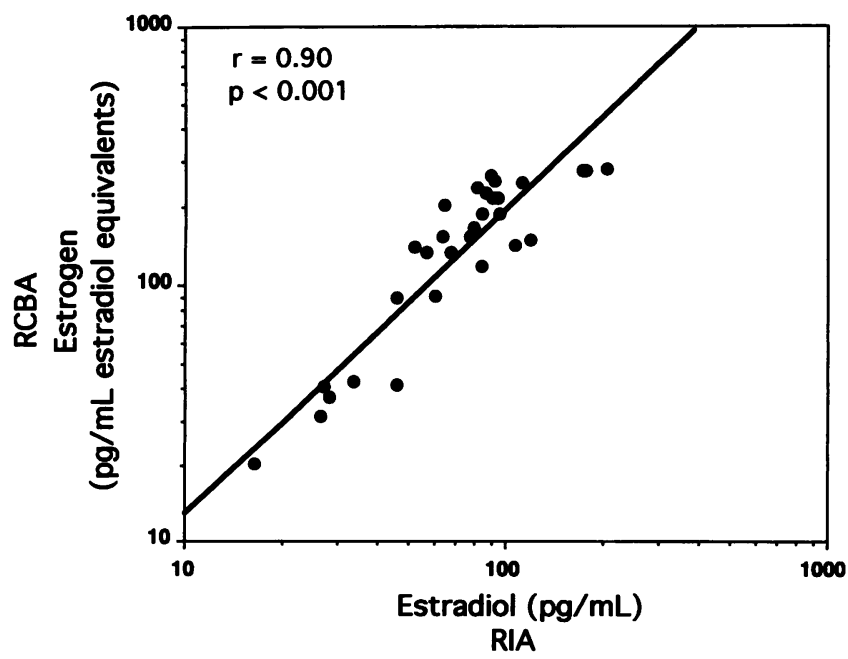

Figure 2. Accuracy. Linear regression of estrogen levels by the new ultrasensitive RCBA ( $y$ axis) with estradiol levels from an existing RIA $(x$ axis). $\mathrm{pg} / \mathrm{ml}$ ) (Fig. 4). The mean estrogen level in prepubertal girls, $0.6 \pm 0.6 \mathrm{pg} / \mathrm{ml}$ estradiol equivalents (range $<0.02-2.2 \mathrm{pg}$ / $\mathrm{ml})$, was significantly greater $(P<0.05)$ (Fig. 4). Estradiol levels did not correlate significantly with age or body mass index in girls or boys and did not correlate with testicular volume in boys (data not shown).

\section{Discussion}

We have developed a new ultrasensitive RCBA to measure estrogen with a sensitivity of $<0.02 \mathrm{pg} / \mathrm{ml}$ estradiol equivalents. Most commercially available radioimmunoassays for estradiol report detection limits of $10-20 \mathrm{pg} / \mathrm{ml}$. The best research assays report detection limits of $2-10 \mathrm{pg} / \mathrm{ml}$. Therefore, the sensitivity of this assay is at least 100 -fold greater than the best existing research assays.

The first estrogen assays were bioassays based upon biological effects such as vaginal cornification (25), vaginal mitosis and epithelial thickening (26), vaginal metabolic activity (27), and uterine weight (28-30). Physico-chemical methods were next used, including colorimetry $(31)$, fluorimetry $(31,32)$, gas-liquid chromatography, and radioimmunoassay (33). By the early 1970s, radioimmunoassays for estradiol, estrone, and estrone sulfate had been developed which had sensitivities as low as $5 \mathrm{pg} / \mathrm{ml}$ (34-40). Antibodies against estradiol were discovered subsequently that permitted sensitivities as low as 2 $\mathrm{pg} / \mathrm{ml}(41,42)$. The ultrasensitive RCBA, by exploiting the potential for signal amplification in a genetically engineered biological system, further increases the sensitivity of estrogen measurement by two orders of magnitude.

There are several possible explanations for the greatly increased sensitivity of this assay compared with radioimmunoassays. First, the human estrogen receptor is probably overexpressed in this system. Therefore, even if the fraction of occupied estrogen receptors is low at the least detectable concentration, the actual concentration of occupied receptors 


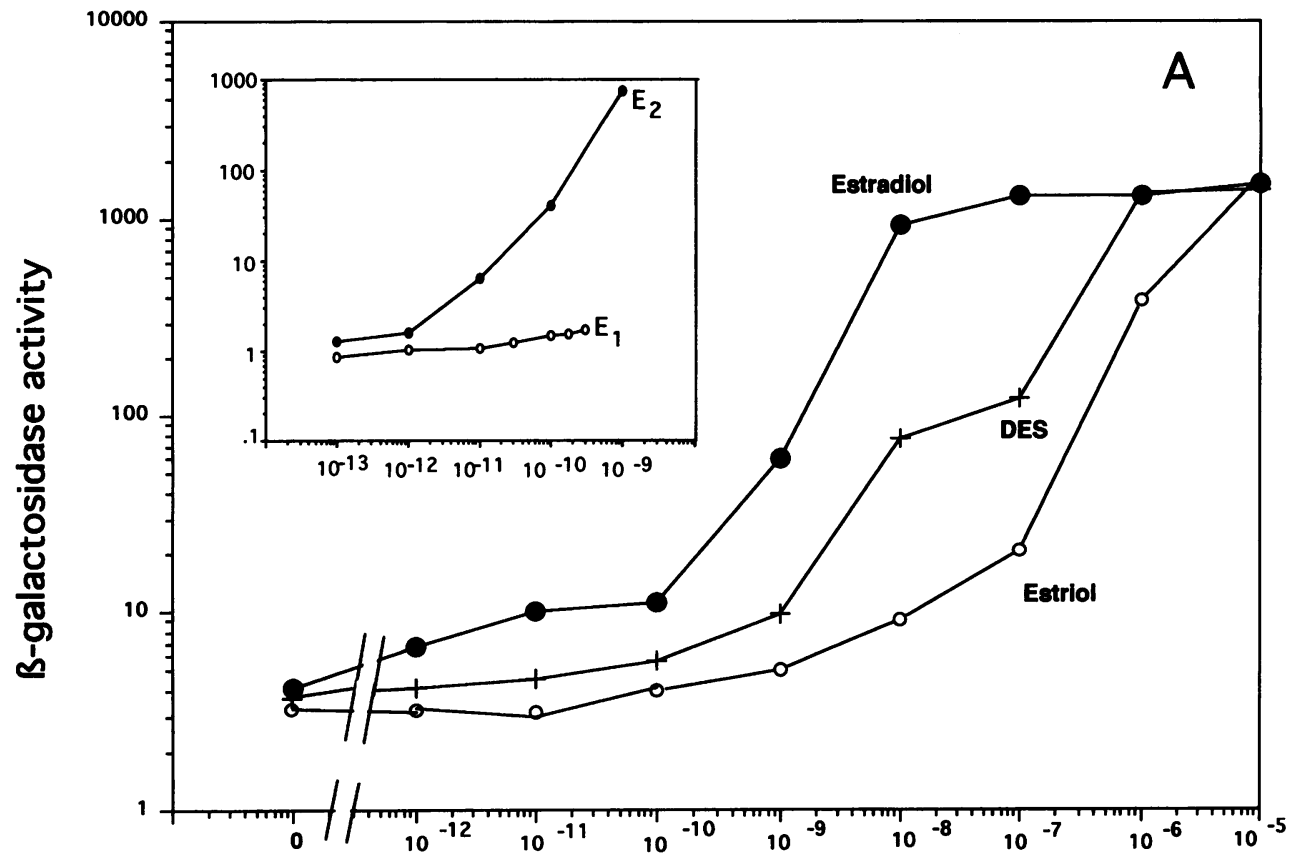

\section{Concentration (M)}

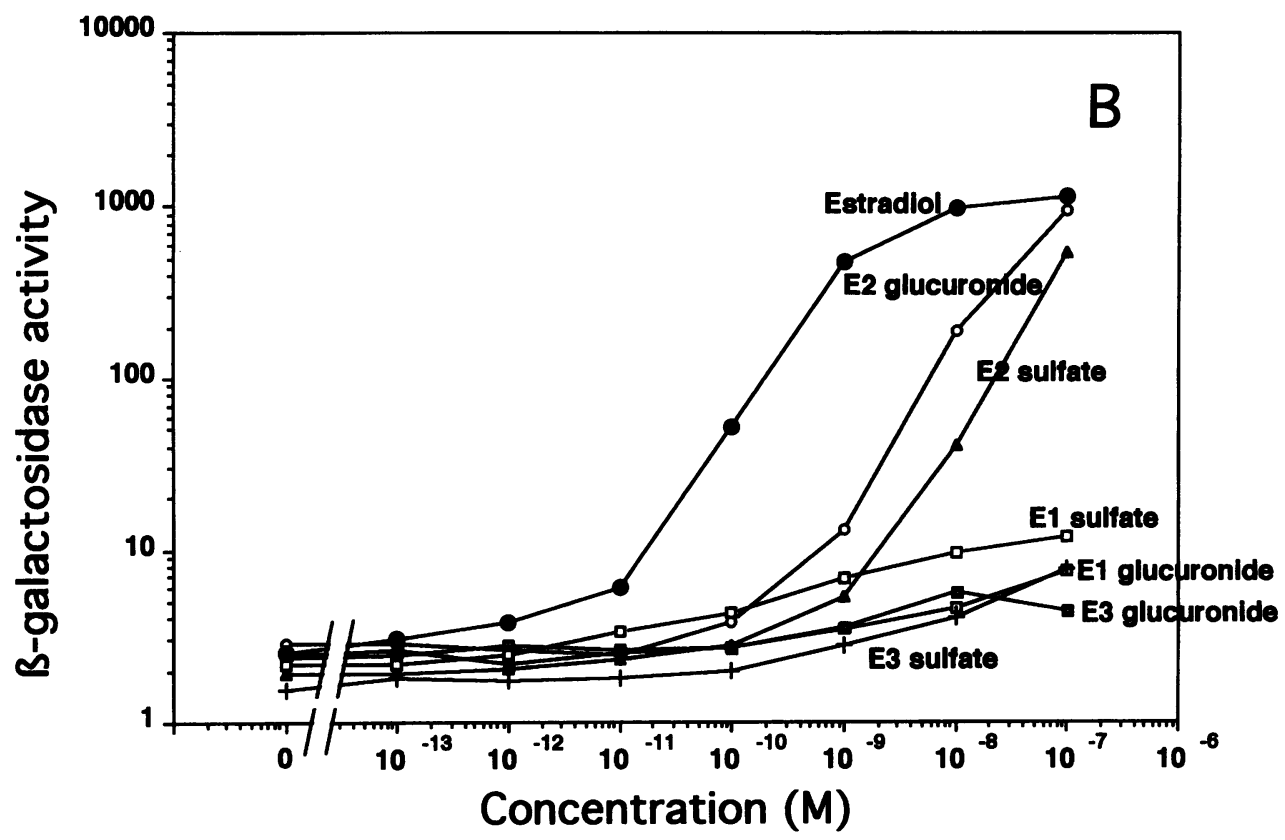

Figure 3. $A$ and $B$ Show cross-reactivities of estrogens and estrogen metabolites in the RCBA. $\beta$-Galactosidase activity is shown on the $y$ axis versus the steroid concentration on the $x$ axis. $E$ 1, estrone; $E 2$, estradiol; $E 3$, estriol. The inset in $A$ shows the cross-reactivity of estrone over the physiological range of estrone concentrations. The unit of $\beta$-galactosidase activity is 1,000 times the change in optical density $(416 \mathrm{~nm})$ per minute divided by the optical density of the cells. may still reach the threshold for biological activity. Second, the frog vitellogenin ERE produces a high-amplitude response to estrogen and the tandem arrangement of two EREs in the reporter plasmid may amplify the effect. Third, the very low background in the absence of estrogen and the 1,000-fold amplification by estrogen also contribute to assay sensitivity.

The assay was unexpectedly specific for estradiol compared with other estrogens such as estrone and estriol. The explanation may lie in part with the ether extraction. There may also be an intrinsically greater activation of the estrogen receptor/ERE complex in this system by estradiol than by the other estrogens. Other theoretical explanations for the specificity for estradiol include greater metabolism of estrone or estriol by the yeast during the 8-h incubation, or a greater adsorption of estrone or estriol by nonreceptor components of the incubation. Regardless of mechanism, however, the practical implication is that estradiol is the principal endogenous compound that reacts in the assay.

We have used this assay to measure estrogen levels in normal prepubertal girls and boys. The mean level in girls was 0.6 $\mathrm{pg} / \mathrm{ml}$ estradiol equivalents. The mean level in boys was 0.08 $\mathrm{pg} / \mathrm{ml}$ estradiol equivalents. Previous reports of estradiol levels in prepubertal children include the description by Forest et al. (9) and others (10-12) of a neonatal surge of estradiol and 


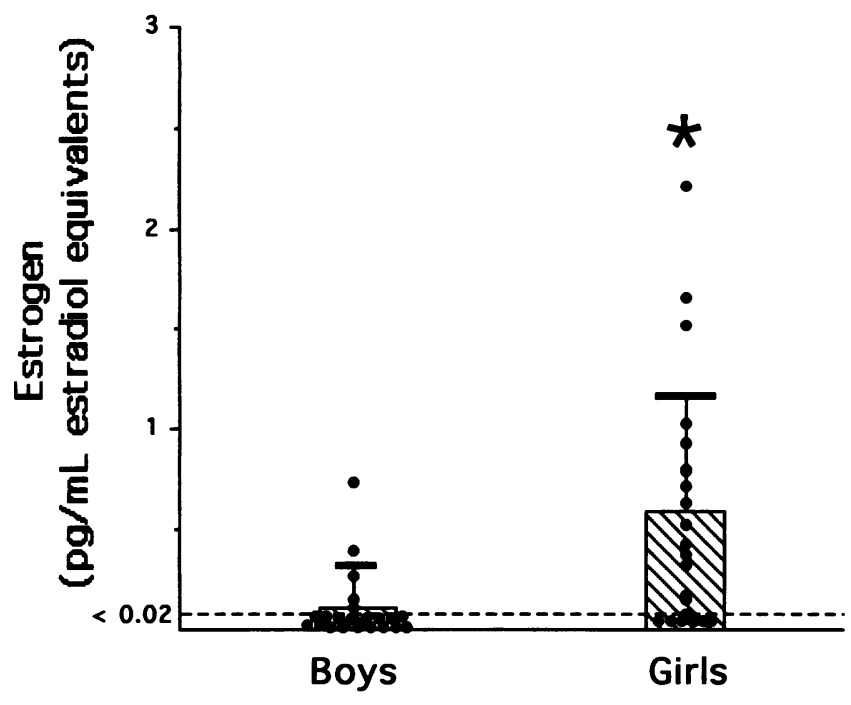

Figure 4. Estrogen levels in normal prepubertal boys and girls. Error bars represent $\pm 1 \mathrm{SD}$. $* P<0.05$ compared with levels in boys.

descriptions by others of estradiol levels in older prepubertal children that were $\sim 8 \mathrm{pg} / \mathrm{ml}$ and were similar in both boys and girls (Fig. 5) (13-16). However, we conclude that these measurements in older prepubertal children, which were near the detection limit of the radioimmunoassays, primarily reflected assay blank, since the levels in both sexes were at least 10-fold higher than were obtained with the ultrasensitive assay (Fig. 5).

There was no correlation between estrogen levels and age, body mass index, or testicular volume in our normal prepubertal subjects. However, more patients, covering a wider range of age and body mass, are needed to define the effect of age and body mass on estrogen level during the prepubertal years.

Our results indicate that prepubertal girls have significantly higher estrogen levels than prepubertal boys. We hypothesize that the higher estradiol levels in prepubertal girls may contribute to their greater rate of skeletal maturation, their earlier pubertal onset, and, ultimately, their earlier cessation of growth, in comparison to boys.

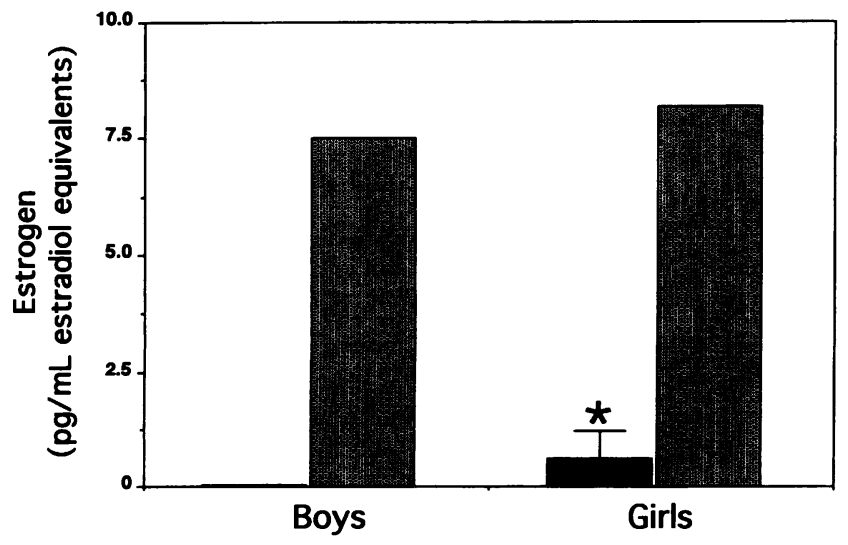

Figure 5. Comparison between estrogen levels. Estrogen levels in prepubertal girls and boys by the ultrasensitive RCBA (solid bars) and previously reported estradiol levels by an RIA (hatched bars) $(13)$. ${ }^{*} P<$ 0.05 compared with the levels measured by the same assay in boys.
The availability of this new ultrasensitive assay makes it possible to address previously unanswerable questions concerning the role of estrogen in normal and pathologic states. Potential physiologic applications include an improved understanding of estrogen secretion during infancy (9-11), childhood $(12,13$, 37 ), and menopause (38-40), including the diurnal variation in secretion and the potential cyclicity associated with premenarcheal follicular maturation and atresia (43). Pathologic applications include the pathophysiology of premature thelarche (44), the differential diagnosis and monitoring of treatment for precocious puberty (45), and optimization of treatment for estrogendependent neoplasms such as breast cancer (46). The assay should also help clarify the role of estrogen in normal male physiology and in feminizing disorders. Much future work will be needed to address these and other areas.

\section{References}

1. Garibaldi, L. R., T. Aceto, Jr., and C. Weber. 1993. The pattern of gonadotropin and estradiol secretion in exaggerated thelarche. Acta Endocrinol. 128:345350 .

2. Marshall, W. A., and J. M. Tanner. 1969. Variations in the pattern of pubertal changes in girls. Arch. Dis. Child. 44:291-303.

3. Caruso-Nicoletti, M., F. Cassorla, M. Skerda, J. L. Ross, D. L. Loriaux, and G. B. Cutler, Jr. 1985. Short term, low dose estradiol accelerates ulnar growth in boys. J. Clin. Endocrinol. \& Metab. 61:896-898.

4. Vanderschueren-Lodeweyckx, M., G. Massa, M. Maes, M. Craen, G. VanVliet, C. Heinrichs, and P. Malvaux. 1990. Growth-promoting effect of growth hormone and low dose ethinyl estradiol in girls with Turner syndrome. J. Clin. Endocrinol. \& Metab. 70:122-126.

5. Ross, J. L., F. G. Cassorla, M. C. Skerda, I. M. Valk, D. L. Loriaux, and G. B. Cutler, Jr. 1983. A preliminary study of the effect of estrogen dose on growth in Turner's syndrome. N. Engl. J. Med. 309:1104-1106.

6. Ross, J. L., F. G. Cassorla, G. Carpenter, L. M. Long, M. S. Royster, D. L. Loriaux, and G. B. Cutler, Jr. 1988. The effect of short term treatment with growth hormone and ethinyl estradiol on lower leg growth rate in girls with Turner syndrome. J. Clin. Endocrinol. \& Metab. 67:515-518.

7. Greulich, W. W., and S. I. Pyle. 1959. Radiographic Atlas of Skeletal Development of the Hand and Wrist. Stanford University Press, Stanford, CA. 255 pp.

8. Laue, L., J. Jones, K. M. Barnes, and G. B. Cutler, Jr. 1993. Treatment of familial male precocious puberty with spironolactone, testolactone, and deslorelin. J. Clin. Endocrinol. \& Metab. 76:151-155.

9. Forest, M. G., E. Peretti, and J. Bertrand. 1976. Hypothalamic-pituitarygonadal relationships in man from birth to puberty. Clin. Endocrinol. 5:551-569.

10. Reyes, F. I., R. S. Boroditsky, J. S. D. Winter, and C. Faiman. 1974 Studies on human sexual development. II. Fetal and maternal serum gonadotropin and sex steroid concentrations. J. Clin. Endocrinol. \& Metab. 8:612-617.

11. Shutt, D. A., L. D. Smith, and R. P. Shearman. 1974. Oestrone, oestradiol17 beta and oestriol levels in human foetal plasma during gestation and at term. J. Endocrinol. 60:333-341.

12. Kenny, F. M., Angsusingha, D. Stinson, and H. Hotchkiss. 1973. Unconjugated estrogens in the perinatal period. Pediatr. Res. 7:826-831.

13. Bidlingmaier, F., M. Wagner-Barnack, O. Butenandt, and D. Knorr. 1973 Plasma estrogens in childhood and puberty under physiologic and pathologic conditions. Pediatr. Res. 7:901-907.

14. Baker, H. W., H. G. Burger, D. M. deKretser, B. Hudson, S. O'Connor, C. Wang, A. Mirovics, J. Court, M. Dunlop, and G. C. Rennie. 1976. Changes in the pituitary-testicular system with age. Clin. Endocrinol. 5:349-372.

15. Belgorosky, A., and M. A. Rivarola. 1988. Progressive increase in non sex hormone-binding globulin-bound testosterone and estradiol from infancy to late prepuberty in girls. J. Clin. Endocrinol. \& Metab. 67:234-237.

16. Ducharme, J. R., M. G. Forest, E. Peretti, M. Sempe, R. Collu, and J. Bertrand. 1976. Plasma adrenal and gonadal sex steroids in human pubertal development. J. Clin. Endocrinol. \& Metab. 42:468-476.

17. Picard, D., B. Khursheed, M. J. Garabedian, M. G. Fortin, S. Lindquist, and K. R. Yamamoto. 1990. Reduced levels of hsp90 compromise steroid receptor action in vivo. Nature (Lond.). 348:166-168.

18. Fuqua, S. A. W., S. D. Fitzgerald, G. C. Chamness, A. K. Tandon, D. P. McDonnell, Z. Nawaz, B. W. O'Malley, and W. L. McGuire. 1991. Variant human breast tumor estrogen receptor with constitutive transcriptional activity. Cancer Res. 51:105-109.

19. McDonnell, D. P., Z. Nawaz, C. Densmore, N. L. Weigel, T. A. Pham, J. H. Clark, and B. W. O'Malley. 1991. High level expression of biologically 
active estrogen receptor in Saccharomyces cerevisiae. J. Steroid Biochem. Mol. Biol. 39:291-297.

20. Pham, T. A., Y. -P. Hwung, D. Santiso-Mere, D. P. McDonnell, and B. W. O'Malley. 1992. Ligand-dependent and -independent function of the transactivation regions of the human estrogen receptor in yeast. Mol. Endocrinol. 6:1043-1050.

21. Moehle, C. M., M. W. Ayanardi, M. R. Kolodny, F. J. Park, and E. W. Jones. 1987. Protease B of Sacchromyces cerevisiae: isolation and regulation of the PRB1 structural gene. Genetics. 115:255-263.

22. Menzel, R. 1989. A microtiter plate-based system for the semiautomated growth and assay of bacterial cells for $\beta$-galactosidase activity. Anal Biochem. 181:40-50.

23. Yocum, R. R., S. Hanley, R. West, Jr., and M. Pitashne. 1984. Use of lacZ fusions to delimit regulatory elements of the inducible divergent GAL1GAL10 promoter in Sacchromyces cerevisiae. Mol. Cell. Biol. 4:1985-1998.

24. Miller, J. H. 1972. Experiments in Molecular Genetics. Cold Spring Harbor Laboratory, Cold Spring Harbor, NY. 352-355.

25. Allen, E., and E. A. Doisy. 1923. Ovarian hormone. JAMA J. Am.( Med. Assoc.). 81:819-821.

26. Martin, L., and P. J. Claringbold. 1960. The mitogenic action of oestrogens in the vaginal epithelium of the ovariectomized mouse. J. Endocrinol. 20:173186.

27. Martin, L. 1960. The use of 2-3-5-triphenyltetrazolium chloride in the biological assay of oestrogens. J. Endocrinol. 20:187-197.

28. Lauson, H. D., C. G. Heller, J. B. Golden, and J. B. Sevringhaus. 1939. Immature rat uterus in the assay of estrogenic substances and a comparison of estradiol, estrone and estriol. Endocrinology. 24:35-44.

29. Evans, J. S., L. Hines, R. Varney, and F. C. Koch. 1940. The comparative assay of gonadotropic substances on rats, mice and chicks. Endocrinology. 26:1005.

30. Dorfman, R. I., and A. S. Dorfman. 1954. Estrogen assays using the rat uterus. Endocrinology. 55:65.

31. Ittrich, S., E. Forchielli, W. H. Perjoff, and I. Dorfman. 1963. Methods of biochemical analysis. In Interscience. Vol. 2. D. Glic, editor. New York. 69.

32. Bates, R. W., and H. Cohen. 1950. Experimental basis for selecting the optimal conditions for quantitative fluorometry of natural estrogens. Endocrinology. 47:166-192.

33. Abraham, G. E. 1975. Radioimmunoassay of steroids in biological fluids. J. Steroid Biochem. 6:261.
34. Loriaux, D. L., H. J. Ruder, and M. B. Lipsett. 1971. The measurement of estrone sulfate in plasma. Steroids. 18:463-472.

35. Ruder, H. J., L. Loriaux, and M. B. Lipsett. 1972. Estrone sulfate: production rate and metabolism in man. J. Clin. Invest. 51:1020-1033.

36. Nagai, N., and C. Longcope. 1971. Estradiol-17 $\beta$ and estrone: studies on their binding to rabbit uterine cytosol and their concentration in plasma. Steroids. 17:631-647.

37. Spratt, D. I., C. Longcope, P. M. Cox, and S. T. Bigos. 1993. Differential changes in serum concentration of androgens and estrogens (in relation with cortisol) in postmenopausal women with acute illness. J. Clin. Endocrinol. \& Metab. 76:1542-1547.

38. Longcope, C., C. Franz, C. Morello, R. Baker, and C. C. Johnston, Jr. 1986. Steroid and gonadotropin levels in women during the peri-menopausal years. Maturitas. 8:189-196.

39. Longcope, C., and J. H. Pratt. 1978. Relationship between urine and plasma estrogen ratios. Cancer Res. 38:4025-4028.

40. Longcope, C., D. Watson, and K. I. Williams. 1974. The effects of synthetic estrogens on the metabolic clearance and production rates of estrone and estradiol. Steroids. 24:15-30.

41. England, B. G., G. D. Niswender, and A. R. Midgley, Jr. 1974. Radioimmunoassay of estradiol-17 beta without chromatography. J. Clin. Endocrinol. \& Metab. 38:42-50.

42. Korenman, S. G., R. H. Stevens, L. A. Carpenter, M. Robb, G. D. Niswender, and B. M. Sherman. 1974. Estradiol radioimmunoassay without chromatography: procedure, validation and normal values. J. Clin. Endocrinol. \& Metab. 38:718-720.

43. Hansen, J. W., H. J. Hoffman, and G. T. Ross. 1975. Monthly gonadotropin cycles in premenarcheal girls. (Wash. DC) Science. 190:161-163.

44. Pescovitz, O. H. 1993. The clinical spectrum of female isosexual precocious puberty. In Sexual Precocity. G. D. Grave and G. B. Cutler, Jr., editors. Raven Press, New York 97-108.

45. Boepple, P. A., M. J. Mansfield, H. Landy, and W. F. Crowley, Jr. 1993. GnRH agonist therapy of central precocious puberty: should the goal be complete pituitary-gonadal suppression? In Sexual Precocity. G. D. Grave and G. B. Cutler, Jr., editors. Raven Press, New York. 11-26.

46. Demers, L. M., A. Lipton, H. A. Harvey, K. B. Kambic, H. Grossberg, C. Brady, and R. J. Santen. 1993. The efficacy of CGS 20267 in suppressing estrogen biosynthesis in patients with advanced stage breast cancer. J. Steroid Biochem. Mol. Biol. 44:687-691. 